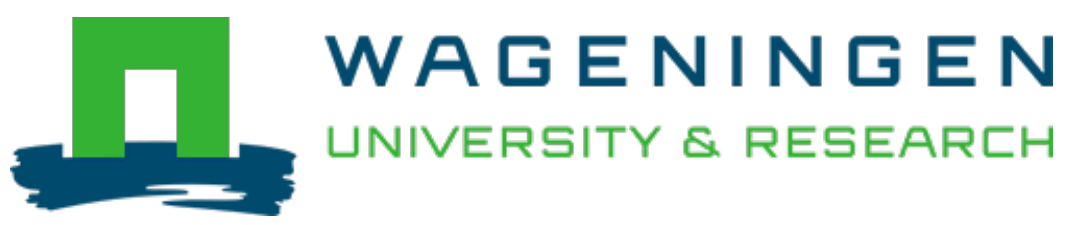

\title{
A Reliability Analysis of Rainwater Catchment System
}

Water Resources

Ammar Adham, Adham; Abed, Rasha; Ritsema, Coen

https://doi.org/10.1134/S0097807821030027

This publication is made publicly available in the institutional repository of Wageningen University and Research, under the terms of article $25 \mathrm{fa}$ of the Dutch Copyright Act, also known as the Amendment Taverne. This has been done with explicit consent by the author.

Article $25 \mathrm{fa}$ states that the author of a short scientific work funded either wholly or partially by Dutch public funds is entitled to make that work publicly available for no consideration following a reasonable period of time after the work was first published, provided that clear reference is made to the source of the first publication of the work.

This publication is distributed under The Association of Universities in the Netherlands (VSNU) 'Article $25 \mathrm{fa}$ implementation' project. In this project research outputs of researchers employed by Dutch Universities that comply with the legal requirements of Article $25 \mathrm{fa}$ of the Dutch Copyright Act are distributed online and free of cost or other barriers in institutional repositories. Research outputs are distributed six months after their first online publication in the original published version and with proper attribution to the source of the original publication.

You are permitted to download and use the publication for personal purposes. All rights remain with the author(s) and / or copyright owner(s) of this work. Any use of the publication or parts of it other than authorised under article $25 \mathrm{fa}$ of the Dutch Copyright act is prohibited. Wageningen University \& Research and the author(s) of this publication shall not be held responsible or liable for any damages resulting from your (re)use of this publication.

For questions regarding the public availability of this publication please contact openscience.library@wur.nl 


\title{
A Reliability Analysis of Rainwater Catchment System
}

\author{
Ammar Adham $^{a, *}$, Rasha Abed ${ }^{b, * *}$, and Coen Ritsema ${ }^{b, * * *}$ \\ ${ }^{a}$ Department of Civil Engineering, College of Engineering, University of Anbar, Baghdad, 55431 Iraq \\ ${ }^{b}$ Soil Physics and Land Management Group, Wageningen University, PB Wageningen, 6708 The Netherlands \\ *e-mail:engammar2000@uoanbar.edu.iq \\ **e-mail:rha.abed@gmail.com \\ ***e-mail: coen.ritsema@wur.nl
}

Received July 27, 2019; revised March 10, 2020; accepted May 29, 2020

\begin{abstract}
This article examines the reliability of rainwater harvesting (RWH) systems in subcatchment area. Using water balance simulation and two definitions of this value (time-based and volumetric ones), the reliability of rainwater harvesting systems for 25 locations in Medenine's dryland agricultural areas in south-eastern Tunisia is assessed. Extensive computer software was created using modelling idea for daily water balance, and three meteorological extremes, i.e. wet, average and dry years, were selected by analysing historical 20year daily rainfall data to assess RWH system performance. Results stated that for wet climatic conditions, volumetric reliability of around $30-70 \%$ can be attained, whereas for these circumstances, only $10-24 \%$ time-based reliability can be accomplished. The method described in this article can also be applied to other arid and semi-arid areas by using daily rainfall data to predict water savings and the reliability of RWH systems.
\end{abstract}

Keywords: rainwater harvesting, reliability, catchment system, Tunisia

DOI: $10.1134 /$ S0097807821030027

\section{INTRODUCTION}

Water scarcity is one of the biggest problems in drought-prone regions, particularly in developing countries, due to increasing water demand, rising population and urban and industrial development [1]. It will therefore be critical to develop policies and technologies to identify alternative water resources, as well as to improve the management and planning water resources. The Rainwater Harvesting System $(\mathrm{RWH})$ is presently getting enhanced attention as alternative water source and is regarded to be promising techniques that can save rainwater for domestic or agricultural use $[1,9,16]$.

Available water supply can be calculated by water balance simulation based on catchment size, dam volume, rainfall, water demand, and evaporation losses $[2,4]$. Modeling the water balance is also helpful in estimating the reliability of RWH, which can be described as the likelihood that the system will provide the necessary water requirement over a specified period of time [6]. Defining the reliability of rainwater harvesting scheme is an important factor in determining the reliability of demand that can lead to underestimation or overestimation of production efficiency and reliability, especially in dry environments [11]. Consequently, determining reliability will be a critical factor in the design of water supplies.
Male and Kennedy [13] assessed the potential rainwater use in Portland Oregon for domestic purposes, paying particular attention to the reliability of rainwater collection. They outlined the procedure based on the quantity of rainfall gathered, household demand, and storage tank capability using water balance. Results showed that the storage tank capacity, together with the size of the catchment area, is critical in determining the system's reliability. Imteaz [8] created tank tool using the modelling idea for the daily water balance. For several Australian towns including Melbourne, the advanced tool was widely used to analyse the reliability of rainwater tanks. Karim [10] examined how reliable certain size of rainwater tank is in terms of annual quantity and meeting the daily expected requirement in Bangladesh megacity. Lawrence and Lopes [12] performed reliability analyses of rainwater harvesting tanks for three Texas towns under various rainfall circumstances and various scenarios. Rainwater harvesting system's reliability is essential because citizens want to understand that water source can be dependent on it [14]. However, to explore the applicability and reliability of the rainwater harvesting scheme in the small sub-catchment, no in-depth research has yet been performed.

The main objective of this research was to use the water balance simulation strategy to evaluate the reli- 


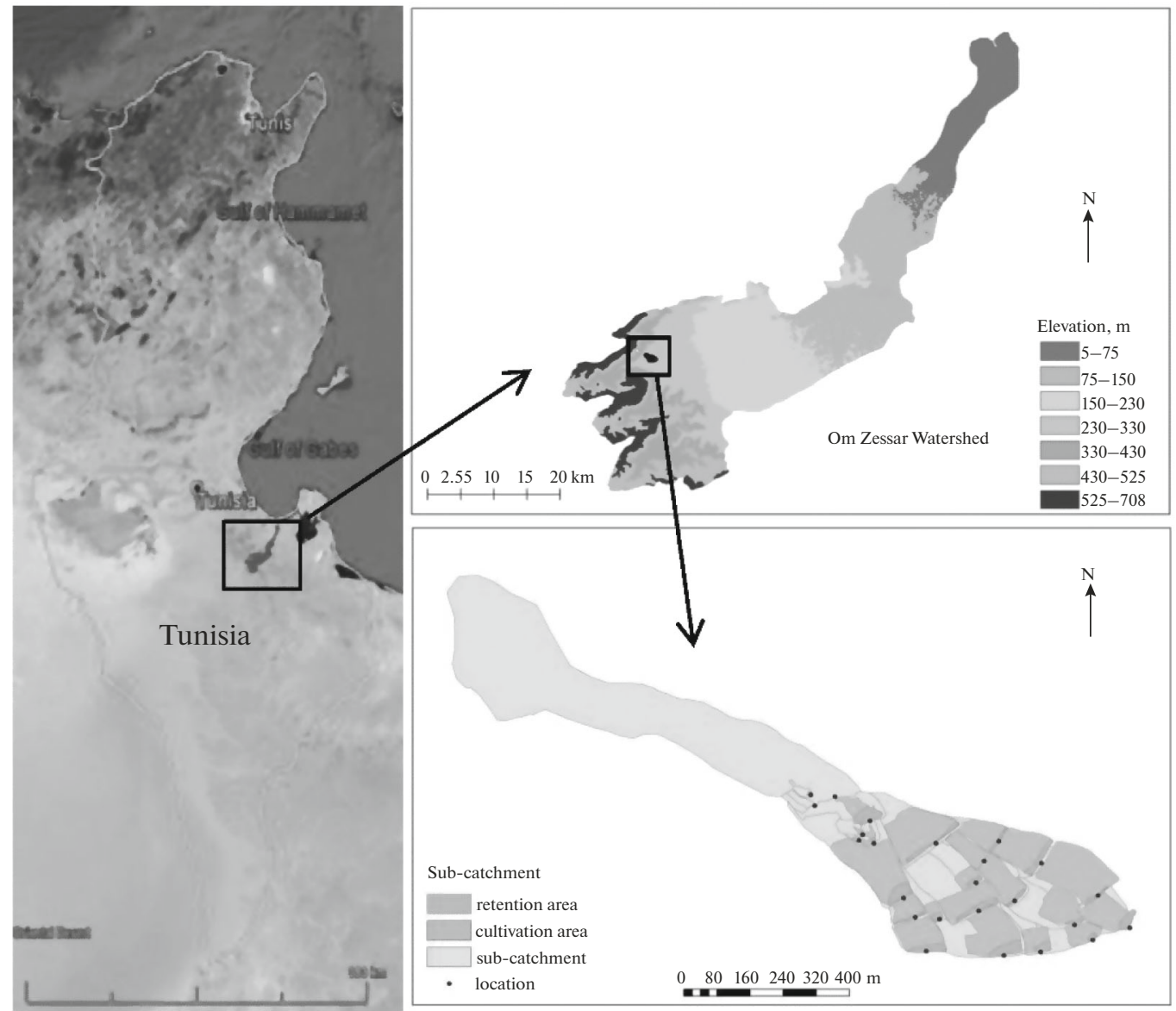

Fig. 1. Location of wadi Oum Zessar watershed and the test sub-catchment.

ability of RWH systems in small sub-catchment. This research therefore has the following goals:

(a) assess the performance of rainwater systems using the water balance model;

(b) determine the volumetric and time-based reliability of RWH systems in small sub-catchment.

\section{MATERIALS AND METHODS Study Area}

The watershed of Oum Zessar in south-eastern Tunisia's Medenine province includes area of $367 \mathrm{~km}^{2}$. For this case research, 50-ha catchment was chosen in the upstream watershed region. There are 25 sub-catchments in this catchment (Fig. 1). The area is characterised by arid Mediterranean climate with $150-230 \mathrm{~mm} / \mathrm{y}$ rainfall, $19-22^{\circ} \mathrm{C}$ annual temperature and $1450 \mathrm{~mm} / \mathrm{y}$ potential evapotranspiration [5].

Two main types of RWH structures have been built by local farmers to cope with water scarcity and to harvest rainfall/runoff to meet the water requirements of rainfed crops and trees: jessour (in moderate to steep slopes) and tabias (in gentle slopes). Each jessr (singu- lar of jessour) or tabia consists of three components: impluvium or catchment area that provides runoff water; the terrace or cultivation area where runoff water is gathered and plants or trees are grown; and the dyke, which is a barrier to capture water and sediment. The dyke's shape and size are distinct, they have no specified layout. Each dyke has a spillway to regulate water flow between dykes (menfes if the spillway is on one or both sides and masref if the spillway is in the middle of the dyke) [3].

\section{Data Collection}

Daily precipitation as well as maximum and minimum temperature data were collected from two nearby meteorological stations at the Institute des Régions Arides (IRA) and Medenine/Tunisia. In order to investigate the reliability, the rainfall information for 20 years was evaluated to determine the three contrasting meteorological years, i.e. wet, dry, and average years. The respective years with annual maximum and minimum rainfall were correspondingly regarded to be wet and dry year. The year with an average annual rainfall of nearly 20 years was regarded as average year. 
Each sub-catchment's physical features were evaluated. The soil texture was acquired by gathering samples, and the area slope was determined using field observation, digital elevation model (DEM) and geographic information system (GIS) in each sub-catchment. Infiltration rates were tested in the field using double-ring infiltrometer and the runoff coefficients were measured at several places in each sub-catchment using rainfall simulator. These data types were used as input for the model of water harvesting (WHCatch) [5].

\section{Water Harvesting Model}

The water balance of the 25 sub-catchments was evaluated based on the crop water requirements (demand), the rainfall-runoff relationship (supply) and the design of the RWH (storage) structures. The difference between total input and output was calculated as the change in water storage within the volume. There are usually two primary components in catchment: runoff area and reservoir area. We analysed the water balance of these two elements, among other subcatchments, and evaluated RWH's performance throughout the system to improve the RWH system's actual storage.

According to Boers [7] the water-balance equation of the area can be written in units of volume $\left(\mathrm{m}^{3}\right)$ as:

$$
\Delta S=I-Q,
$$

where $\Delta S$ is change of storage over specified period of time, $I$ is the inflow, and $Q$ is the outflow, all in $\mathrm{m}^{3}$.

Recognition of the different kinds of in- and outflow permits more comprehensive water balance equation:

$$
\Delta S=Q_{\text {runoff }}+Q_{\text {rainfall }}+Q_{\text {in }}-Q_{\text {out }}-\text { Inf }-E T_{\mathrm{c}},
$$

where $Q_{\text {in }}$ is the volume of inflow from upstream catchmen t(s), $Q_{\text {out }}$ is the volume of overflow from the retention basin to the next catchment (s), Inf is the infiltration loss from the retention basin obtained from the measured infiltration rate in each sub-catchment using the double-ring infiltrometer, $E T_{\mathrm{c}}$ is the maximum crop evapotranspiration, $Q_{\text {runoff }}$ is the volume of runoff into the retention basin from the impluvium (runoff area) calculated as:

$$
Q_{\text {runoff }}=0.001 C P A_{r},
$$

where $C$ is the mean annual runoff coefficient measured in the field with the rain simulator, $P$ is the mean annual precipitation (mm), and $A_{r}$ is the impluvium or runoff area $\left(\mathrm{m}^{2}\right)$, and where $Q_{\text {rainfall }}$ is the rainfall in the retention basin, calculated as:

$$
Q_{\text {rainfall }}=0.001 P A_{b},
$$

where $A_{b}$ is the area of the retention basin $\left(\mathrm{m}^{2}\right)$.

$E T_{\mathrm{c}}$ was calculated from the field measurements as described by Schiettecatte et al. (2005) for the same watershed. These authors used data from the Mede-
Table 1. Rainfall, potential evapotranspiration (PET), maximum crop evapotranspiration $\left(E T_{\mathrm{c}}\right)$, and olive crop coefficient $k_{\mathrm{c}}$ (after [5])

\begin{tabular}{l|c|c|c|c}
\hline Month & Rainfall, mm & PET, mm & $\mathrm{ET}_{\mathrm{c}}, \mathrm{mm}$ & $k_{\mathrm{c}}$, for olive \\
\hline Jan & 37.5 & 69.6 & 27.8 & 0.40 \\
Feb & 30.6 & 88.6 & 35.4 & 0.40 \\
Mar & 40.0 & 121.2 & 66.7 & 0.55 \\
Apr & 16.3 & 159.3 & 79.6 & 0.50 \\
May & 11.2 & 198.4 & 89.3 & 0.45 \\
Jun & 1.00 & 213.5 & 85.4 & 0.40 \\
Jul & 0.00 & 234.8 & 82.2 & 0.35 \\
Aug & 2.00 & 220.9 & 77.3 & 0.35 \\
Sep & 17.1 & 166.6 & 75.0 & 0.45 \\
Oct & 23.0 & 126.8 & 63.4 & 0.50 \\
Nov & 19.9 & 91.1 & 41.0 & 0.45 \\
Dec & 36.7 & 67.4 & 26.9 & 0.40 \\
\hline
\end{tabular}

nine meteorological station to calculate the average annual potential for evapotranspiration using the Penman-Monteith technique (PET) for 1985-1995.

The maximum $E T_{\mathrm{c}}$ was calculated by:

$$
E T_{\mathrm{c}}=P E T k_{\mathrm{c}},
$$

where $k_{\mathrm{c}}$ is the crop coefficient. The values for PET, $E T_{\mathrm{c}}$, and $k_{\mathrm{c}}$ for olive trees are presented in Table 1.

\section{The Water Harvesting at Catchment Level (WHCatch) Model}

All input data had already been stored and made accessible in Excel, so in Excel we developed straightforward Visual Basic for Applications (VBA) macro. This macro conducted the above calculations and stored in the respective cells the resulting values. The code consisted of module for WHCatch and module for Sub-catchment Class. The latter contained all subcatchment's characteristics and routines for carrying out some fundamental computations. There were some private subroutines and three public subroutines in the WHCatch module. The VBA macro will not be seen by common consumers of the Excel workbook. It will only be essential to enter the coding region if new functionality is needed. In the same Excel workbook, all output is stored and displayed, and the data 
obtained with this program can be read into GIS application. In most cases, the shape file with the area layout and the sub-catchment identification numbers (IDs) are available. This allows the sub-catchment ID in the shape file being combined with the Excel workbook ID.

\section{Reliability Analysis}

Two kinds of reliability have been calculated in this study. Time based reliability is calculated using the following equation of Imteaz [9]:

$$
R_{t}=\frac{T_{d}-U_{d}}{T_{d}} \times 100,
$$

where $R_{t}$ is the timebased reliability (\%), $U_{d}$ is the total number of days when harvested rainwater was unable to meet the daily water demand alone and $T_{d}$ denotes the total number of days ( 365 or 366 ) in a calendar year.

Where the volumetric reliability, $R_{V}$ is given by:

$$
R_{v}=\frac{\sum\left((V W)_{d}-V D_{d}\right)}{\sum V W_{d}},
$$

where $V W_{d}$ is the total volume of water demand in a year and $V D_{d}$ is the total water deficiency for year.

\section{Sensitivity Analysis}

Sensitivity analyses were conducted to evaluate the impacts of the runoff coefficient on the effectiveness of rainwater storage (volumetric reliability). Several sensitivity graphs illustrating effectiveness relationships with demand fraction and storage fraction were provided. The demand fraction $(D / Q)$ is defined as follows:

$$
\frac{D}{Q}=\frac{V W_{d}}{V W_{s}}
$$

where $V W_{s}$ is the volume of rainwater supply in year and $V W_{d}$ is the total volume of water demand in year.

The storage fraction $(S / Q)$ is defined as:

$$
\frac{S}{Q}=\frac{\text { Storage capacity }\left(\mathrm{m}^{3}\right)}{V W_{s}} .
$$

\section{RESULTS AND DISCUSSION}

The preliminary assessment was performed to examine the impact of storage capacity on daily reliability and to define the storage capacity that provides the optimum average reliability value for each unit. Simulations of water balance were performed on daily scale; the daily average reliability of each site was calculated over the entire period of analysis. Then, the related percentiles values were estimated.

\section{Reliability Analysis}

The time-based reliability relationships for various catchment sizes with storage capacity were shown in Fig. 2. For three scenarios (wet, average and dry), cases reliability increases up to storage volume of $112 \mathrm{~m}^{3}$ (threshold), therefore becoming stable. The threshold value presents the point when reliability becomes independent of increases in storage capacity. It seems logical to suppose that wet year would be more reliable than the average and dry years because more rainfall would keep a full storage.

Volumetric reliability, i.e. the percentage of water savings for several catchment sizes with variable storage volume, was shown in Fig. 3. It is evident from this figure that the impact of storage size on volumetric reliability shows comparable trend as the time based reliability. The value of volumetric reliability can be observed to be higher than the time-based reliability considered for the catchment.

\section{Sensitivity Analysis}

For the runoff coefficient, which varies from 0.2 to 0.5 (C in Fig. 4), sensitivity analysis was carried out. Water efficiency vs. demand fraction curves with regard to runoff coefficients shows that under the wet climatic condition the runoff coefficient has negligible impact on water efficiency (Fig. 4).

Figure 5 illustrates the impact of the runoff coefficient on water efficiency. Results indicate that efficiency tends to increase with increasing storage fraction. Analysis shows that decrease of the runoff coefficient from 0.5 to 0.2 leads to decrease in effectiveness approximately of $2-3 \%$.

\section{CONCLUSIONS}

This study examines how reliable certain size of rainwater storage is in terms of annual volume and meeting the expected daily requirement. The reliability of rainwater harvesting systems for the outlet of 25 locations situated in Medenine's dryland agricultural fields in south-eastern Tunisia is assessed using water balance simulation and two reliability definitions (time-based and volumetric reliabilities).

The reliability relationships with the different storage capacity have shown that both time base and volumetric reliabilities are increasing for the wet year up to storage volume of $112 \mathrm{~m}^{3}$ (threshold). The application of the concept of thresholds allows property owners to achieve most system's reliability while minimizing installation costs. Consequently, reliability does not increase as the storage volume tries to increase. Volumetric reliability was found to be $10-35 \%$ higher than the time-based reliability for all cases. With the growing demand for water, both time-based and volumetric reliabilities reduced. 


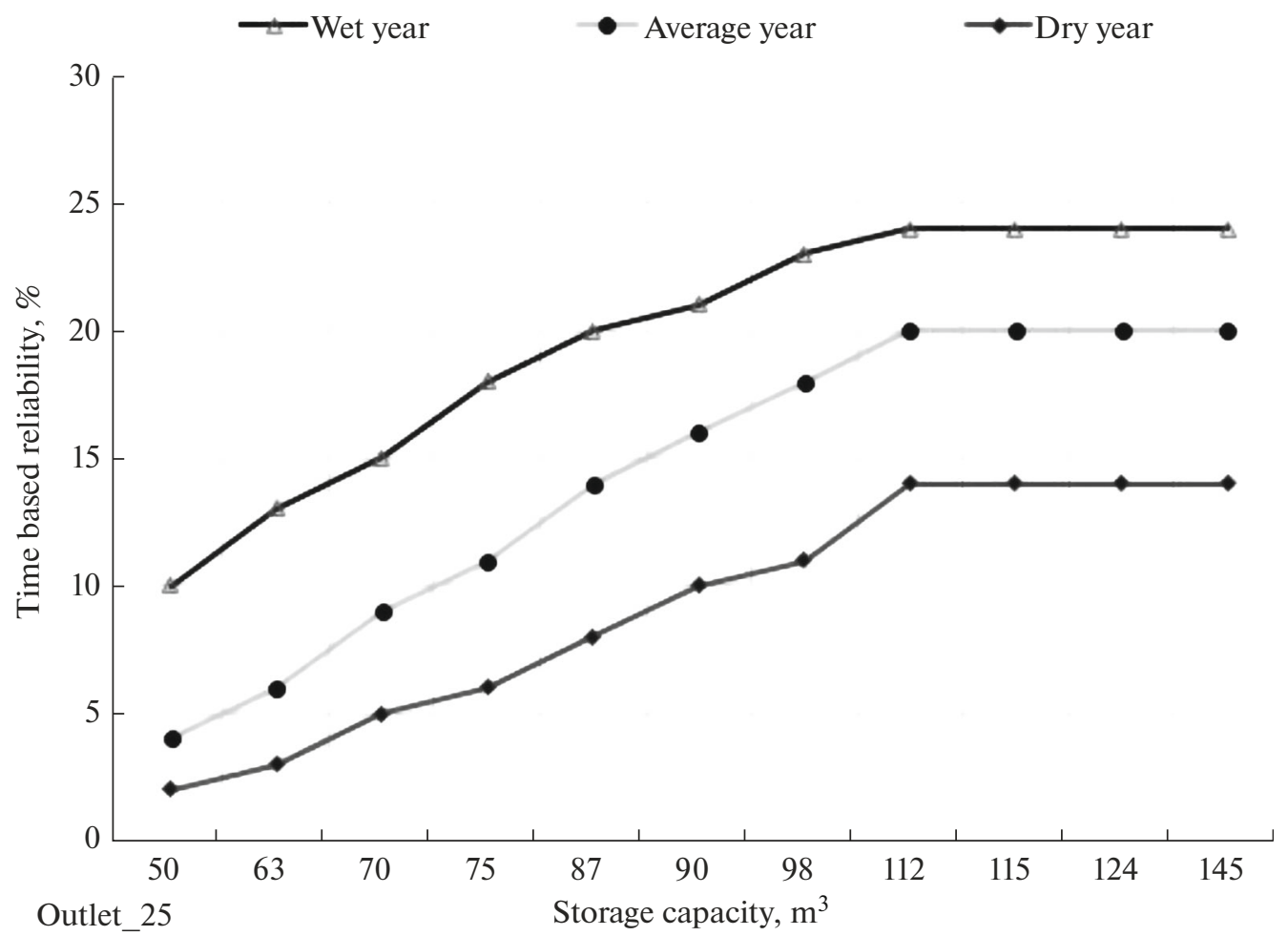

Fig. 2. Time based reliability relationships against storage capacity for different meteorological/climatic scenarios.

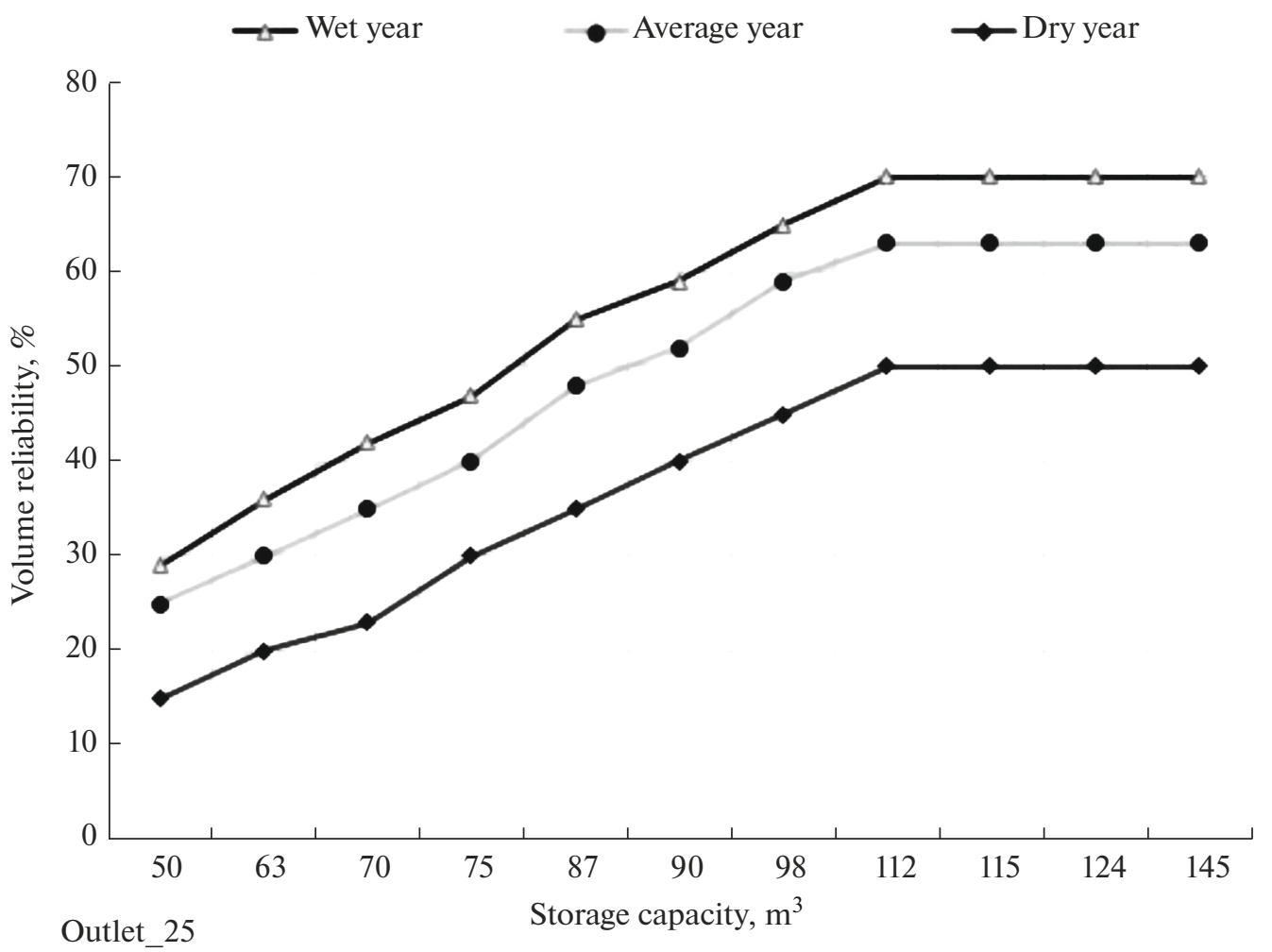

Fig. 3. Volumetric reliability relationships versus storage capacity for different meteorological/climatic scenarios. 


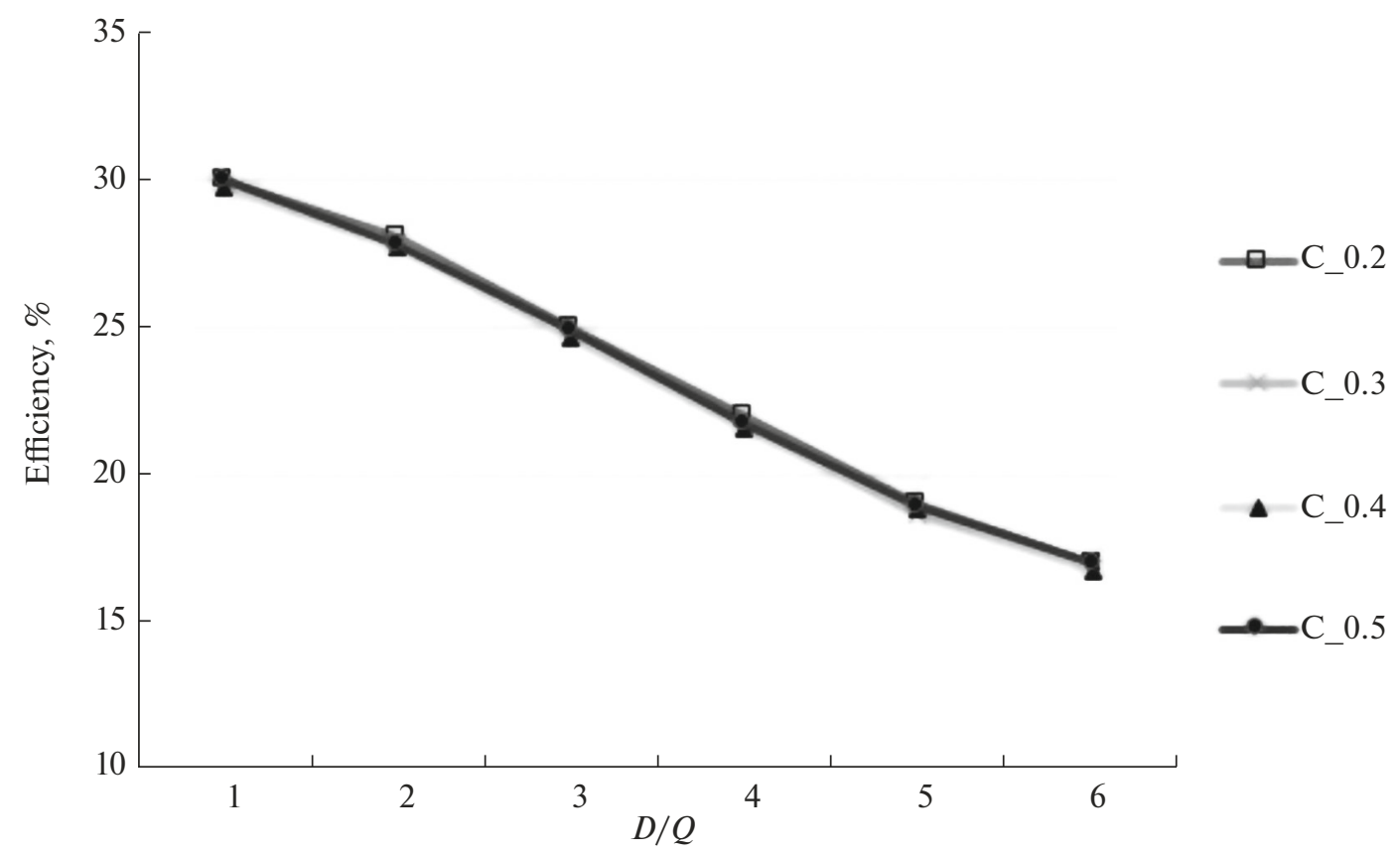

Fig. 4. Water saving efficiency relationships versus demand fraction $(D / Q)$ for different runoff coefficients.

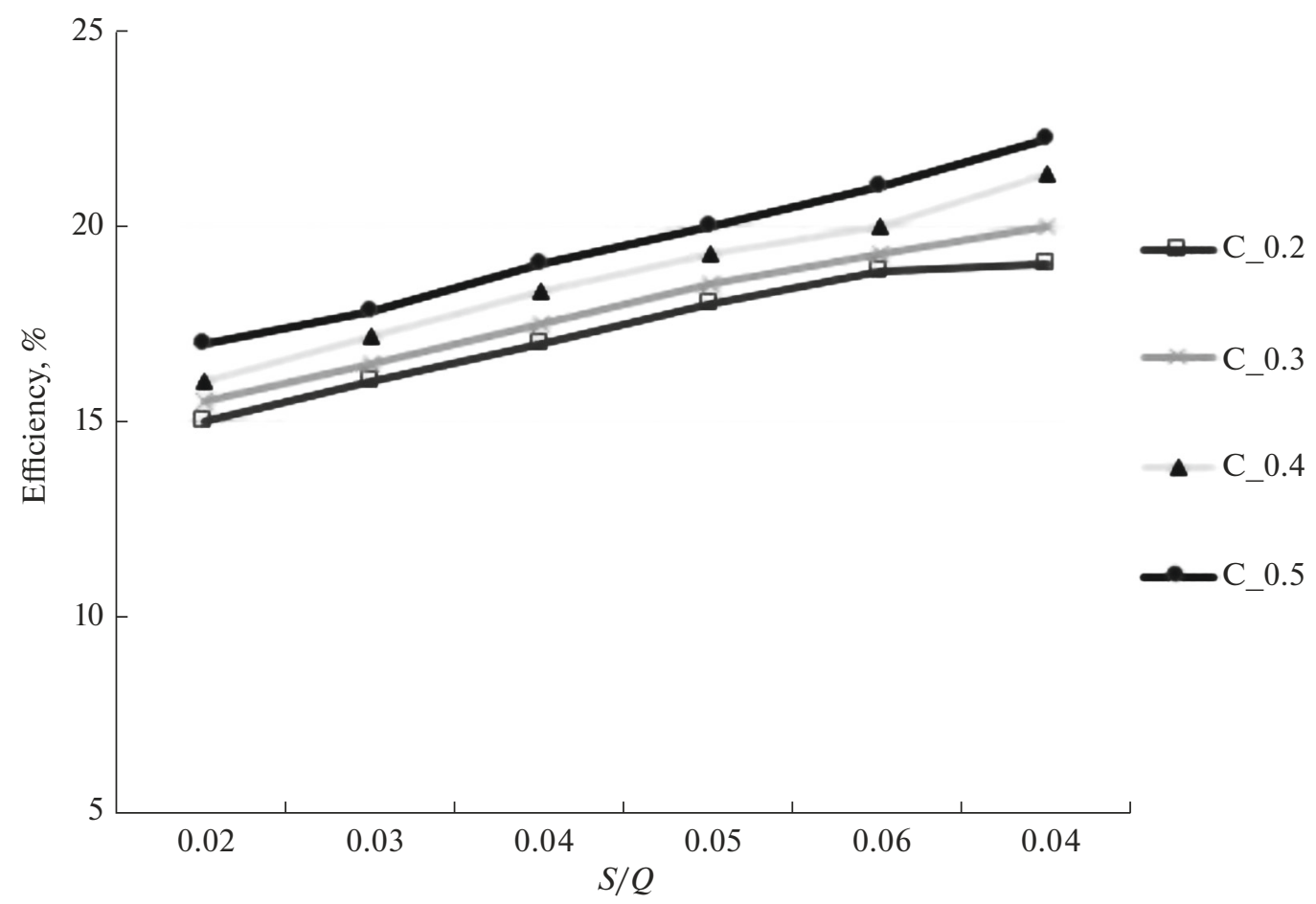

Fig. 5. Water saving efficiency relationships with the storage fraction $(S / Q)$ for different runoff coefficients.

Finally, it is essential to understand reliability because it tells decision-makers and families how many days the rainwater collection scheme can meet their water requirements throughout the year.

\section{REFERENCES}

1. Adham, A., Wesseling, J. G., Abed, R., Riksen, M., Ouessar, M., and Ritsema, C. J., Assessing the impact of climate change on rainwater harvesting in the Oum 
Zessar watershed in Southeastern Tunisia, Agriculture Water Manage., 2019, vol. 221, pp. 131-140.

2. Adham, A., Riksen, M., Ouessar, M., Abed, R., and Ritsema, C., Development of Methodology for Existing Rainwater Harvesting Assessment in (semi-) Arid Regions, in Water and Land Security in Drylands, Springer, Cham, 2017, pp. 171-184.

3. Adham, A., Riksen, M.J.P.M., Ouessar, M., and Ritsema, C.J., A methodology to assess and evaluate rainwater harvesting techniques in (semi-) arid regions, Water, 2016, vol. 8, no. 5, p. 198.

4. Adham, A., Sayl, K.N., Abed, R., Abdeladhim, M.A., Wesseling, J.G., Riksen, M., and Ritsema, C.J., A GIS-based approach for identifying potential sites for harvesting rainwater in the Western Desert of Iraq, Int. Soil Water Conservation Res., 2018, vol. 6, no. 4, pp. 297-304.

5. Adham, A., Wesseling, J.G., Riksen, M., Ouessar, M., and Ritsema, C.J., A water harvesting model for optimizing rainwater harvesting in the wadi Oum Zessar watershed, Tunisia, Agriculture Water Manage., 2016, vol. 176, pp. 191-202.

6. Baek, C.W. and Coles, N.A., Defining reliability for rainwater harvesting systems, in Proc. Int. Congr. Model. Simulation MODSIM 2011.

7. Boers, T.M., Zondervan, K., and Ben-Asher, J., Micro-catchment-water-harvesting (MCWH) for arid zone development, Agriculture Water Manage., 1986, vol. 2, pp. 21-39. https://doi.org/10.1016/0378-3774(86)90003-X

8. Imteaz, M.A., Ahsan, A., Naser, J., and Rahman, A. Reliability analysis of rainwater tanks in Melbourne using daily water balance model, Resour. Conserv. Recycl., 2011 , vol. 56 , no. 1 , pp. $80-86$.
9. Jafarzadeh, A., Bilondi, M.P., Afshar, A.A., and Yaghoobzadeh, M., Reliability estimation of rainwater catchment system using future GCM output data (case study: Birjand city), Eur. Water, 2017, vol. 59, pp. 169175 .

10. Karim, M.R., Bashar, M.Z.I., and Imteaz, M.A., Reliability and economic analysis of urban rainwater harvesting in a megacity in Bangladesh, Resour. Conserv. Recycl., 2015, vol. 104, pp. 61-67.

11. Karim, M.R., Rimi, R.A., and Billah, M.S., Reliability analysis of household rainwater harvesting tanks in the coastal areas of Bangladesh using daily water balance model, in 20th Int. Congress Model. Simulation, 2013, pp. 2639-2645.

12. Lawrence, D. and Lopes, V.L., Reliability analysis of urban rainwater harvesting for three Texas cities, $J$. Urban Environ. Engineering, 2016, vol. 10, no. 1, pp. 124134.

13. Male, J.W. and Kennedy, M.S., Reliability of rainwater harvesting, WIT Transactions on the Built Environ., 2006, vol. 86.

14. Rahman, A., Aurib, K., Datta, D., and Yunus, A., Reliability Analysis and Water Modeling of Optimum Tank Size for Rainwater Harvesting in Two Salinity Affected Areas of Bangladesh, J. Environ. Engineering and Studies, 2017, vol. 2, nos. 2, 3.

15. Schiettecatte, W., Ouessar, M., Gabriels, D., Tanghe, S., Heirman, S., and Abdelli, F., Impact of water harvesting techniques on soil and water conservation: a case study on a micro catchment in southeastern Tunisia, J. Arid. Environ., 2005, vol. 61, pp. 297-313. https://doi.org/10.1016/j.jaridenv.2004.09.022

16. Traboulsi, H. and Traboulsi, M., Rooftop level rainwater harvesting system, Appl. Water Sci., 2017, vol. 7, no. 2 , pp. $769-775$. 